\title{
Assessing Excellence Management in the Light of the European Excellence Model at Taif University
}

Shda Ibrahim Faraj*

Education College, Taif University, Saudi Arabia

Corresponding author: Shda Ibrahim Faraj, E-mail: shada.f@tu.edu.sa

\section{ARTICLE INFO}

Article history

Received: September 01, 2018

Accepted: October 29, 2018

Published: October 31, 2018

Volume: 6 Issue: 4

Conflicts of interest: None

Funding: None

\begin{abstract}
This study assessed the excellence management at Taif University by considering the European Model of Excellence (EFQM) in terms of the following dimensions: (1) leadership, policies and strategies, (2) human resources, (3) processes, (4) partnerships and resources, (5) products and services, (6) human resource results, (7) society results and (8) key performance results. The study followed a descriptive (survey and comparative) approach. Data were collected using a questionnaire administered to a random sample of faculty members $(n=284)$ of Taif University. The results indicated statistically significant differences in the score of management of excellence for Taif University in the light of the EFQM from the point of view of the sample members in reference to the following variables: gender, academic rank, and years of experience. No statistically significant differences were observed in the total score for the practice of excellence management at Taif University considering the EFQM from the point of view of the study sample members in reference to the following variables: type of college and number of training programs. The main recommendation of the study was to urge the university to increase efforts to attain a higher level of excellence management practice considering the EFQM.
\end{abstract}

Key words: European Model of Excellence (EFQM); Excellence management; Gender; Faculty members

\section{INTRODUCTION}

The current era is characterized by rapid change; as a result, higher education faces many challenges that have motivated higher education institutions to seek quality and excellence to increase their effectiveness, adapt their outputs to the labor market, and achieve their desired goals. Scientific and technical advances have caused the emergence of a high-speed management era in response to change with challenges, the acquisition of modern capabilities, and the speed of innovation, innovation, and development. Al-Hadi (2013) suggests that this development has caused academic institutions to engage in knowledge, culture, vocational developments, research and community development; to focus on developing policies and strategies, changing traditional systems, developing the skills, common values, and effective leadership styles of university employees; and to strive to achieve the satisfaction of beneficiaries and society.

In this study, excellence management is defined as undertaking a range of activities and procedures that support the achievement of the desired results according to its objectives and has a highly competitive advantage in providing services to the beneficiaries and the community. Meanwhile, European Model of Excellence (EFQM) is defined as a set of criteria established by EQM to achieve excellence in institu- tion performance. These criteria include leadership, policies, and strategies, human resources, partnership and resources, processes, products and services, customer outcomes, human resources results, community outcomes, and key performance results.

Al-Farah and Sahmoud (2015) noted that the strategies employed by the universities are geared toward the implementation of excellence management models. Perhaps the most important of these models is the European Model for Excellence Management of the European Foundation for Quality Management. Alsalateen (2014) pointed out that some academic plans in international universities emphasized that the management of academic excellence and its achievement are becoming more important, a requirement that is necessary for universities and places it among their priorities. A study by Qawasmeh and Al Bourini (2016) recommended that the administration of excellence should be given sufficient attention by the university administration, the self-evaluation of the university level of academic excellence and the training of staff to deal with the standards of the European model of excellence management should be done regularly. A study by Garbarova (2017, p. 335) also confirmed that the EFQM can be used as a tool to improve the results of organizations, including human resources management, ensure development and increase competitiveness. 
Excellence in universities can be achieved by highlighting the degree of excellence management practice at Taif University using the EFQM and its different dimensions.

\section{Problem Statement}

The importance of the quality of Saudi universities has become an urgent necessity, especially in the era of rapid changes. Therefore, the trend toward excellence is inevitable; the gap among international universities can be narrowed with steady progress in all fields. Alsalateen (2014) noted that recent studies supported by the Ministry of Higher Education at the level of Saudi universities, which are performed by a research team from a Saudi university, have identified a flaw in achieving excellence.

The experience of a researcher in administrative work at the university indicated an urgent need for an effective evaluation tool that can be used to assess the performance of the university and promote the academic and administrative process and the compatibility of the outputs of the university to the labor market, such as the European model of excellence, which is one of the most famous models of excellence and the most suitable for application in university institutions. This finding prompted the researcher to evaluate the practice of excellence management at Taif University considering the EFQM

\section{Research Questions}

1. What is the degree of excellence management practice at Taif University considering the light of the EFQM in terms of the following dimensions: (1)leadership, (2) policies and strategies, (3) human resources, (4) processes, (5) partnership and resources, (6) processes, products and services, customer results, main human resources results?

2. Do any statistically significant differences exist in the degree of excellence management practice at Taif University considering the EFQM due to the following variables: gender - the type of college - the number of years of service - academic rank - the number of training programs offered at the university?

\section{LITERATURE REVIEW}

\section{Institutional Excellence}

Al-Qarazi (2018) suggests that excellence is a state of managerial innovation and organizational excellence that achieves high levels of performance and implementation of academic, administrative, financial and other processes in university education, which enable achievements that surpass the universities' competition and satisfy the beneficiaries and society. According to (Al-Qarazi, 2018), institutional excellence is a modern philosophy that is attributed to the emergence of organizations that have undertaken the task of searching for the best methods for upgrading the organization and developing it to levels that satisfy all stakeholders. It is one of the main objectives of the EFQM, the Malcolm Baldrige of
Quality in the United States of America (MBNQA) and the Pering Deming Organization in Japan.

Soussi (2015) defined institutional excellence as a set of integrated organizational steps and procedures implemented by universities to achieve excellence in several areas, including leadership (partnership, management of processes, and focus on stakeholders) to render the university more competitive among other universities in bridging the gap between the university and the labor market.

Excellence management consists of the activities organized by the universities in cooperation with its employees to achieve a high degree of mastery of work and excellence in the performance of the university and to reach a level of performance that is distinct to achieve or exceed the wishes and expectations of all beneficiaries, considering the criteria of the European model of excellence by its nine standards.

\section{The European Excellence Model}

The European Award for Quality and Excellence was established after a consortium of 14 European countries formed the European Foundation for Quality Management (Hydari and Davoodi, 2013). The model criteria were established in 1988 to adopt a criterion for assessing the advanced institutions of the European Quality Award, which created the European Award for Quality. This European Award for Quality is awarded annually to honor the most successful institutions and excellence. The mission of this organization is to achieve outstanding performance and promote the competitiveness of European organizations around the world.

The EFQM is based on a set of fundamental concepts and values that are indispensable for organizational performance regardless of the size of an organization and its organizational functions. These concepts and values include results achievement, customer satisfaction, leadership effectiveness, employee management, participation, continuous learning, innovation, improvement, and development of partnership and responsibility.

Al-Qarazi (2018) stated that the model was developed in 1992 as a framework for evaluating applications for the European Quality Award. The model was developed and modified in 1999 and updated in 2003 to consider the current thinking environment and changes in the work environment. Steed (2001) asserted that the European Excellence Model (EFQM) is a practical management tool for helping organizations establish an appropriate management system via standards to measure an organization's excellence and each activity within or outside the organization and enhanced solutions. Bashiwa, Barwari, and Ishuni (2013) defined the management system as the outstanding practice of managing an organization and achieving results. The institution or organization can attain excellence management if it adheres to the European model of excellence. The European model of excellence includes nine basic criteria in two categories. The first five criteria are considered to be 'possibilities' whereas the remaining four criteria are considered to be 'results' as follows: (Figure.1 )

As shown in the previous figure, the European model provides a specific and distinct methodology that helps management achieve excellence management. The methodology is 


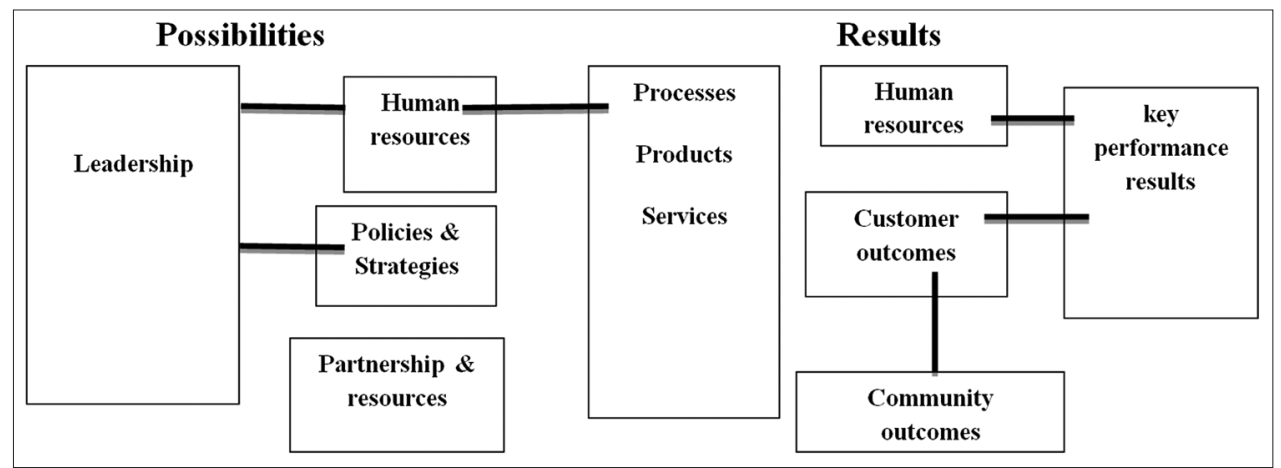

Figure 1. European Excellence Model Criteria ([EFQM], Consortium for Excellence in Higher Education, 2003, p. 1)

referred to as Results, Approach, Deployment, Assessment, Review (RADAR). The methodology assumes the form of a cycle starting with defining the required results. A specific method is employed to achieve results by the activation of indicators, with follow-up, evaluation, and feedback to correct deviations, improve performance and achieve the objectives of learning, initiative, and innovation.

Some researchers in the Consortium for Excellence in Higher Education of Europe assured that the EFQM can be applied at the level of educational institutions, such as school, college, management, and research institute; it requires effective leadership and management commitment (2003).

Meul (2016) explains that the European model of excellence in Europe in higher education has been applied to prepare students for competition in the labor market and active participation in community service and applied to the latest technologies to ensure that European higher education is ready for the future.

\section{Advantages of the European Model (EFQM)}

Nanidal (2015) asserted that the advantages of the European Model of Excellence are its ability to serve as a powerful tool with an objective diagnosis of higher education institutions that are based on facts and evidence and its ability to improve the efficiency of continuous improvement of all processes of higher education institutions. Aref (2013) noted that the model integrates the different development initiatives into the day-to-day processes and procedures of an organization, provides a reference framework for quality management at the university, a self-assessment tool, a structural framework for the university's administrative system and a tool for local and European quality awards.

\section{Previous Studies}

This section includes a presentation of the studies related to the research objective. The presentation considered the chronological order, starting with the most recent studies, including local, Arab and international studies. A study by Zeps, Iljins, and Ribickis, (2017) aims to explore the role of the European Excellence Model (EFQM) in providing an analysis of the potential improvements in the management process of higher education institutions and strategic planning. To achieve the objectives of the study, the strate- gic planning process for the pilot project was evaluated at Riga Technical University in Europe. The main results of the study suggested that Riga Technical University should provide a range of activities to improve strategic planning, internal processes structure and quality management.

A study by Sarialtin (2017) aimed to disclose the application of the EFQM standards at Sakarya University in Turkey by employing standards in the Turkish higher education sector and determine how nationalization can be institutionalized according to its methodology. The main findings of the study revealed that the EFQM is an ongoing management tool for qualitative improvements and the formation of external links with the University constitutes the National Standardized Education Institution. Qawasmeh and Al Bourini, (2016) aimed to identify the level of the practice of managing university excellence at Jadra University from the point of view of employees and students using the European model for excellence and its nine dimensions. The main results of the study indicated that the level of organizational excellence at Jadra University was average.

In 2016, Al-Alfi published a study in which he examined the degree of availability of the European model of excellence and clarified the proposed procedures to satisfy the standards of the European model at the University of Hail. The most important results of the study revealed that the degree of satisfaction with the standards of the European model of excellence at Hail University from the point of view of faculty members was average. The ranking of the questionnaire criteria according to the views of the study sample is listed as follows: partnership and resources criterion, processes standard, results standard, leadership standard, human resource standard, policy, and strategy standard.

Qasmi et al. (2016) assessed the organizational role of EFQM in organizational productivity at Azad Islamic University in Iran. The findings revealed that the model has a role in labor productivity. Issawi (2016) conducted a study to investigate the effect of leadership style on achieving excellence in university performance at Tabuk University and the effect of change management on achieving excellence in university performance at Tabuk University. The most important results of the study revealed that a statistically significant effect of the leadership style on the achievement of excellence in university performance and a significant impact of change management on the achievement of excellence in university performance. 
Table 1. Sample study descriptive

\begin{tabular}{llcccc}
\hline Gender & College & \multicolumn{3}{c}{ Academic rank } & Total \\
\cline { 3 - 5 } & & Professors & Associate Professors & Assistant Professors & \\
\hline Males & Humanities & 34 & 86 & 182 & 302 \\
& Sciences & 45 & 139 & 296 & 480 \\
& Total & 79 & 225 & 478 & 782 \\
\multirow{3}{*}{ Females } & Humanities & 4 & 20 & 152 & 176 \\
& Sciences & 4 & 35 & 284 & 347 \\
& Total & 8 & 55 & 762 & 1129 \\
\hline \multirow{2}{*}{ Total } & & 87 & 280 & & 171 \\
\hline
\end{tabular}

Ahmed (2015) investigated the reality of the institutional performance of the South Valley University considering the criteria of the European model of excellence to identify the impact of gender variables and years of experience. The most important results of the study indicated a lack of statistically significant differences in the total score of the European Excellence Model criteria that are attributable to the type and years of experience.

Nenadal (2015) assessed the total quality of educational institutions in Czech universities according to the European model of excellence. The most important results were described as follows: the EFQM is the most comprehensive tool for evaluating and ensuring the quality of the universities' achievements and evaluating the future potential of the universities using the leading indicators.

Al-Farra and Sahmoud (2015) also examined the reality of excellence management at Al-Aqsa University and methods for developing it according to the EFQM European model. The most important results of the study demonstrated that the level of application of the University of Al-Aqsa's standards of excellence management are less than $60 \%$. The objective of a study by Khawaja and Salami (2013) was to determine the degree of self-assessment of the performance at Azad Islamic University in Iran according to the EFQM. The most important results of the study indicated that the self-evaluation of the university's performance was medium, with the highest possible level of leadership standard, the lowest level of the policy and strategy standard, the highest score in the results criterion for the community service results standard and the lowest score for the human resources management results standard.

A study by Saada (2013) identified the extent to which the leadership standard in Palestinian higher education institutions was applied according to the European model of excellence. The university college of applied sciences, Gaza Strip, was employed as a practical case. Saada concluded that the leadership standard for the European model of excellence was high.

In addition to the previously mentioned studies, Hydari and Davoodi (2013) conducted a study to investigate the relationship between organizational learning and the EFQM. The most important results of the study revealed a significant relationship between organizational learning and the European model of excellence. The best predictor of excellence in universities is the transfer of the integration of knowledge and the system of thinking, openness and experimentation. A study by Abu Basheer (2015) identified the application of excellence considering the EFQM in the Palestinian universities in the Gaza Strip. The most important results of the study indicated that the application of all criteria of excellence exceeded $60 \%$. Due to the gender variable, statistically significant differences were not observed in the responses of the sample of the study of the application of the criteria of excellence potential due to the gender variable.

Based on this review, it can be concluded that:

1. Most studies aimed to discover the degree of practice by higher education universities to manage excellence using the EFQM in foreign, Arab and Saudi universities. Some studies aimed to determine the degree of practice of the leadership standard of the European model of excellence. The study, which is currently being conducted by the University of Applied Sciences in Gaza, identifies the degree of practice of the European model of excellence, similar to a study by Salami, 2013 and Khajeh at Azad Islamic University in Iran. In addition, some studies identified the extent to which the European model of excellence is practiced, similar to a study by Salami, 2013 and Khajeh at the Islamic University of Azad in Iran. This study determines the degree of Taif University's practice of managing excellence considering the European model of excellence.

2. The study of Al-Alfi (2016) and Issawi (2016) is directly applied to Saudi universities, specifically Hail University and Tabuk University. This study is being applied to a Saudi university-Taif University.

3. Most of the results of the measurement of the degree of excellence management practice considering the standards of excellence in the Arab universities were medium, similar to a study by Qawasmeh and AL Bourini, 2016 at the University of Jadra in Palestine a study by Al-Alfi (2016) in Hail in Saudi Arabia. However, the extent of practice for this study was higher than the extent of practice at Al-Aqsa University in Palestine, as noted in a study by Al-Farra and Samhud (2015); the extent of practice in Palestinian universities in the Gaza Strip, as noted in a study by Abu Basheer, 2015; and the extent of practice at South Valley University in Egypt, as noted in a study by Ahmed (2015).

4. Most of the previous studies were conducted by the study community members of the faculty, which confirms that they are among the most important groups in universities that have an active role in university excellence. This 
study corresponds with previous studies regarding the selection of faculty members as a sample of the study.

5. Some previous studies have indicated a high degree of correlation between the variable of the European model of excellence and another variable, as noted in a study by Al-Qasimi and Akron (2016) for the productivity of labor, and a study by Hydari and Davoodi (2016) for organizational learning, which demonstrates the effective role of excellence management in activating organizational aspects in universities. Based on these studies, the researcher concludes the need to conduct this study to evaluate the practice of excellence management at Taif University considering the European model of excellence.

\section{METHODS}

\section{Procedures of the study}

\section{Design}

This study employed a descriptive approach (survey - comparative) to determine the degree of excellence management practice at Taif University considering the European Model of Excellence (EFQM) in terms of nine criteria and determine the differences between the average responses of the sample of the study to these criteria according to the variables of (1) gender, (2) type of college, (3) years of experience, (4) academic rank, and (5) number of training programs provided by the university.

\section{Population}

The study population consists of all (1129) members of the teaching staff of Taif University, according to the statistics from the Deanship of Faculty Affairs at Taif University during the second semester 2017-2018.

\section{Sample}

A random stratified sample was used to ensure that the study population was well represented. The number of responses (284) on the questionnaire, which represent approximately $25 \%$ of the size of the study population, are presented as follows (Table 2):

The following table provides a description of the research sample according to the variables of gender, type of college, number of years of experience, academic rank, and number of training programs offered at the university (Table 3).

\section{Instrument}

The researcher designed the questionnaire in this study to determine the degree of excellence management practice at Taif University considering the EFQM in terms of the criteria of leadership, policies and strategies, human resources, processes, partnership and resources, processes, products and services, human, community outcomes, and key performance outcomes. The researcher has reviewed periodicals,

Table 2. Statistics of the research sample $(n=284)$

\begin{tabular}{|c|c|c|c|c|c|}
\hline \multirow[t]{2}{*}{ Gender } & \multirow[t]{2}{*}{ College } & \multicolumn{3}{|c|}{ Academic rank } & \multirow[t]{2}{*}{ Total } \\
\hline & & Professors & Associate Professors & Assistant Professors & \\
\hline \multirow[t]{3}{*}{ Males } & Humanities & 9 & 22 & 46 & 77 \\
\hline & Sciences & 11 & 35 & 74 & 120 \\
\hline & Total & 20 & 57 & 120 & 197 \\
\hline \multirow[t]{3}{*}{ Females } & Humanities & 1 & 5 & 38 & 44 \\
\hline & Sciences & 1 & 9 & 33 & 43 \\
\hline & Total & 2 & 14 & 71 & 87 \\
\hline Total & & 22 & 71 & 191 & 284 \\
\hline
\end{tabular}

Table 3. Distribution of the research sample according to the research variables

\begin{tabular}{llcc}
\hline Study variables & Categories & Numbers & \% \\
\hline Gender & Males & 197 & 69.4 \\
& Females & 87 & 30.6 \\
Type of college & Humanities & 163 & 57.4 \\
& Sciences & 121 & 42.6 \\
Academic rank & Professors & 22 & 7.7 \\
& Associate professors & 71 & 25.0 \\
The Number of years of experience & Assistant professors & 191 & 67.3 \\
& Less than 10 years & 208 & 73.2 \\
The Number of training programs & More than 10 years & 76 & 26.8 \\
& Less than 10 programs & 225 & 79.2 \\
\hline
\end{tabular}


educational journals, research and previous studies related to the problem of this study and the familiarity with the criteria of the European model of excellence.

\section{Psychometric Characteristics of the Questionnaire in this Study}

\section{Questionnaire Validation}

The validity of the questionnaire was confirmed using two methods: the first method was judgments validity, and the second method was internal consistency. The questionnaire was presented in its preliminary form to a group of faculty members with expertise and experience at the Faculty of Education in Taif University and Umm Al Qura University. A letter that explained the problem and objectives of the study was addressed to the faculty.

The researcher presented this questionnaire to (15) faculty at the Faculty of Education in Taif University and Umm Al Qura University to ascertain the degree of relevance of the statement, its clarity, its relevance to the standard that it measures, and the correctness of the language, as well as consideration of the scale and appropriateness of the questionnaire. Based on the opinions of the faculty on the appropriateness of the questionnaire, and according to their directives and proposals, some of the items were linguistically modified, and the number of the items in the questionnaire increased to (60).

\section{Internal consistency}

The validity of the questionnaire was verified by applying the questionnaire to a sample of 30 randomly selected members/faculty members. The internal consistency was determined by calculating the correlation coefficient between the score of each statement and the total score of the criterion to which this term it corresponds. The results of the internal consistency are presented as follows (Table 4):

Table 4 indicates that the values of the correlation coefficients ranged from 0.65 to 0.73 . All values of the correlation coefficients are positive, high and statistically significant at 0.05 , which indicates internal consistency between the score of each statement and the total score of the dimension to which it corresponds.

\section{Reliability of the questionnaire}

The questionnaire was reliable using the Cronbach's alpha method; the results are presented as follows:

As shown in Table 5, the reliability coefficient of the questionnaire and its dimensions, which ranged from 0.87 to 0.93 , were very high. This finding indicates that the questionnaire has a high degree of reliability.

\section{Last version of the questionnaire}

The questionnaire included two parts. The first part contained personal data in terms of gender, type of college, academic rank, number of years of experience, and number of training programs provided by the university. The second part included 60 items distributed on (9) dimensions, as follows: Table 6.

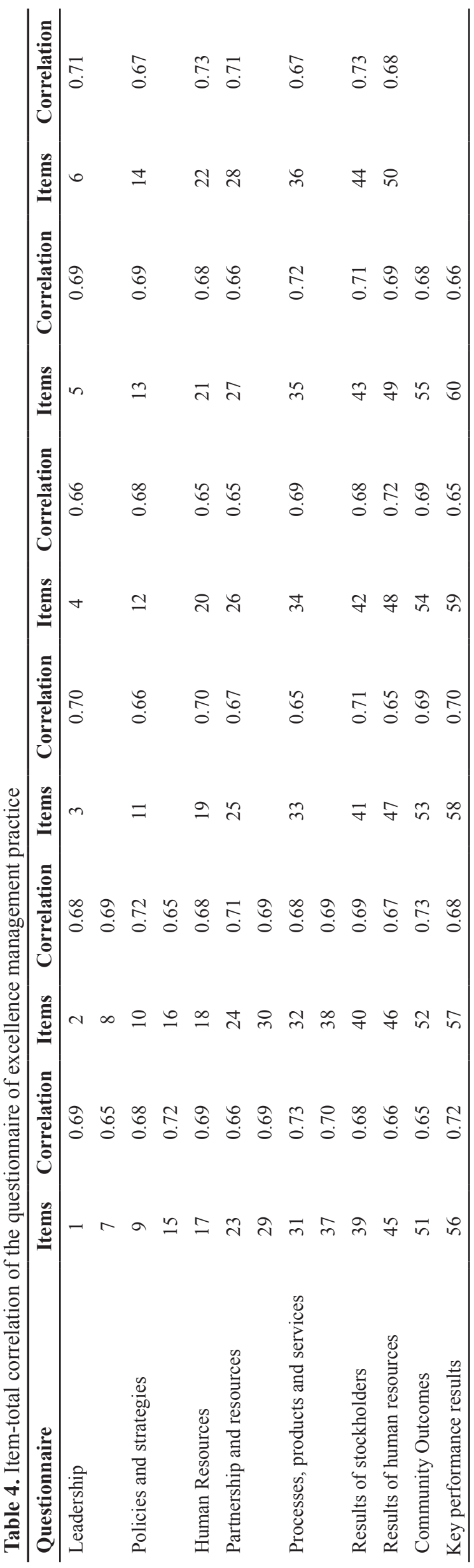




\section{Correction of the questionnaire}

A five-point Likert scale that ranged from one (strongly disagree) to five (strongly agree) was employed. According to the five-point scale, the following criterion was used to judge the degree of response: response range $=$ highest score - lowest score $=5-1=4$.

Category Length $=$ Response Range/Number of Response Classes $=4 / 5=0.8$ (Table 7).

\section{RESULTS}

To answer the first question: "What is the degree of excellence management practice at Taif University considering the EFQM in terms of the following criteria: (leadership, policies and strategies, human resources, processes, partnership and resources, processes, products and services, human resources, community outcomes, and key performance results)?" The arithmetic mean and the standard deviation of the sample responses were calculated based on each EFQM. The general arithmetic mean for each criterion was also calculated; the results were as follows:

Table 8 reveals that the degree of excellence management practice at Taif University, considering the EFQM in terms of the nine criteria is a medium practice and a mean $(\mathrm{M}=3.36)$. Considering the degree to which different standards are prac-

Table 5. Reliability of the questionnaire of excellence management practice

\begin{tabular}{llc}
\hline & Questionnaire dimensions & $\begin{array}{c}\text { Cronbach's } \\
\text { alpha coefficients }\end{array}$ \\
\hline 1 & Leadership & 0.90 \\
2 & Policies and strategies & 0.88 \\
3 & Human Resources & 0.91 \\
4 & Partnership and resources & 0.89 \\
5 & processes, products and services & 0.90 \\
6 & Results of stockholders & 0.87 \\
7 & Results of human resources & 0.89 \\
8 & Community Outcomes & 0.88 \\
9 & Key performance results & 0.91 \\
10 & Total score & 0.93 \\
\hline
\end{tabular}

Table 6. Questionnaire of excellence management practice

\begin{tabular}{llcc}
\hline & Questionnaire dimensions & $\begin{array}{c}\text { Number } \\
\text { of items }\end{array}$ & Items \\
\hline 1 & Leadership & 8 & $1-8$ \\
2 & Policies and strategies & 8 & $9-16$ \\
3 & Human Resources & 6 & $17-22$ \\
4 & Partnership and resources & 8 & $23-30$ \\
5 & Processes, products and services & 8 & $31-38$ \\
6 & Results of stockholders & 6 & $39-44$ \\
7 & Results of human resources & 6 & $45-50$ \\
8 & Community outcomes & 5 & $51-55$ \\
9 & Key performance results & 5 & $56-60$ \\
10 & Total score & 60 & $1-60$ \\
\hline
\end{tabular}

ticed, the leadership standard is ranked first in terms of practice; followed by the results of society in the second order; followed by the key performance results in the third place; the results of the beneficiaries in the fourth order; following the standard of processes, products and services ranked sixth; the human resources results criterion in seventh place; the partnership and resources criterion in the eighth ranking; and finally the policy and strategy standard is ranked ninth.

In response to the second question, which states "Do statistically significant differences exist between the mean scores of the practice of excellence management at Taif University considering the European model of excellence due to the following variables: gender, type of college, academic rank, number of years of experience in the university?"? First: Comparison by gender: The results are listed in the following table:

Table 9 indicates that the values of $(t)$ are (2.04), which are statistically significant at $(0.05)$. The value of the total score is 2.04 , and the differences in favor of females with a mean of $(\mathrm{M}=3.52)$ and a mean of $(\mathrm{M}=3.29)$ for males.

As presented in Table 10, the value of $(\mathrm{t})$ for the total score is (1.30), which is not statistically significant at (0.05).

As can be seen in Table 11, the value of (F) for the total score is (13.96), which is statistically significant at (0.05).

Table 12 reports statistically significant differences at in the total score the level of $(0.05)$ for the practice of the academic rank among the arithmetic means of the responses of the associate professor (3.80), the professor (3.36) and the assistant professor (3.19) in favor of the academic rank of the associate professor.

As shown in Table 13, the value of $(t)$ for the total score was (2.20), which is statistically significant at (0.05). The total score is (2.20), and the differences in favor of less than 10 years with a mean of $(\mathrm{M}=3.43)$ and greater than 10 years and more was $(\mathrm{M}=3.17)$.

Table 14 reveals that the value of $(t)$ for the total score was $(0.88)$, which is statistically insignificant at $(0.05)$. No statistically significant difference exists between the mean scores of excellence management practice at Taif University considering the European model of excellence. However, the number of training programs that have been offered at the university varies.

\section{DISCUSSION}

\section{Discussion of the Results of the First Question}

As shown in Table 8, the degree of excellence management practices at Taif University considering the EFQM in terms

Table 7. Criterion for calculating the mathematical means of the sample responses of the study

\begin{tabular}{llll}
\hline & Means & $\begin{array}{l}\text { Response } \\
\text { (degree of practice) items }\end{array}$ \\
\hline 1 & 1 - less than 1.81 & Strongly Disagree & Low \\
2 & $1.81-$ less than 2.61 & Disagree & Low \\
3 & $2.61-$ Less than 3.41 & Neutral & Average \\
4 & $3.41-$ lower than 4.21 & Agree & High \\
5 & $4.21-5$ & Strongly agree & Very high \\
\hline
\end{tabular}


Table 8. Means and standard deviations of the responses of the study sample

\begin{tabular}{lcccc}
\hline Criteria & Means & Standard Deviation & Degree of practice & Order \\
\hline Leadership & 3.61 & 0.99 & High & 1 \\
Policies and strategies & 3.23 & 0.93 & Average & 9 \\
Human Resources & 3.30 & 0.99 & Average & 5 \\
Partnership and resources & 3.24 & 0.91 & Average & 8 \\
Processes, products and services & 3.29 & 0.92 & Average & 6 \\
Results of stockholders & 3.36 & 0.94 & Average & 4 \\
Results of human resources & 3.28 & 0.88 & Average & 7 \\
Results of society & 3.54 & 0.91 & High & 2 \\
Key performance results & 3.44 & 0.86 & High & 3 \\
Total score & 3.36 & 0.87 & Average & - \\
\hline
\end{tabular}

Table 9. $t$ test to compare the mean scores of the study sample with the total score of the questionnaire by gender

\begin{tabular}{llcccccc}
\hline Criteria & Gender & $\boldsymbol{N}$ & Means & SD & $\boldsymbol{t}$ & $\boldsymbol{D f}$ & sig \\
\hline Total score & Males & 197 & 3.29 & 0.87 & 2.04 & 282 & 0.04 \\
& Females & 87 & 3.52 & 0.85 & & & \\
\hline
\end{tabular}

Table 10. $t$ test to compare the mean scores of the study sample with the total score of the questionnaire by the type of college

\begin{tabular}{clcccccc}
\hline Criteria & $\begin{array}{l}\text { The type of } \\
\text { college }\end{array}$ & $\mathbf{N}$ & Means & SD & $\boldsymbol{t}$ & Df Sig. \\
\hline Total score & Scientific & 163 & 3.30 & 0.90 & 1.30 & 282 & 0.20 \\
& Humanities & 121 & 3.44 & 0.83 & & \\
\hline
\end{tabular}

Table 11. Results of the $F$-test to compare the mean scores of sample responses on the questionnaire by academic rank

\begin{tabular}{llccccc}
\hline Criteria & $\begin{array}{l}\text { Variance } \\
\text { resources }\end{array}$ & $\begin{array}{c}\text { Total } \\
\text { squares }\end{array}$ & $\begin{array}{c}\text { DF } \\
\text { Mean } \\
\text { scores }\end{array}$ & $\boldsymbol{F}$ & Sig \\
\hline Total score & Between groups & 19.42 & 2 & 9.71 & 13.96 & 0.00 \\
& Within groups & 195.47 & 281 & 0.70 & & \\
& Total score & 214.89 & 283 & & & \\
\hline
\end{tabular}

of the nine criteria is a medium practice. The total degree of excellence management practice considering the EFQM at Taif University may be interpreted as a suitable indicator of Taif University's attempt to satisfy the standards of the European Excellence Model and identify the activities that the University should provide for excellence. Therefore, there is a need for continuous work and efforts to achieve a degree of excellence management practice considering the European model. The results of this study are consistent with the results of the study of (Zeps, Iljins \& Ribickis, 2017), which indicates the role of the EFQM in improving strategic planning, internal processes and quality management. A study by Sarialtin (2017) indicates that the EFQM is an ongoing management tool for quality improvements and external linkages with the University. The results of the
Table 12. Schiffe's test of differences in the total score of the practice of standards by academic rank

\begin{tabular}{lcccc}
\hline $\begin{array}{l}\text { Academic } \\
\text { Rank }\end{array}$ & $\begin{array}{c}\text { Mean } \\
\text { scores }\end{array}$ & Professors & $\begin{array}{c}\text { Associate } \\
\text { Professors }\end{array}$ & $\begin{array}{c}\text { Assistant } \\
\text { Professors }\end{array}$ \\
\hline Professors & 3.36 & - & $0.44^{*}$ & 0.17 \\
Associate & 3.80 & & - & $0.61^{*}$ \\
Professors & & & & \\
$\begin{array}{l}\text { Assistant } \\
\text { Professors }\end{array}$ & 3.19 & & & - \\
\hline
\end{tabular}

Table 13. $t$ test to compare the mean scores of the study sample by years of experience

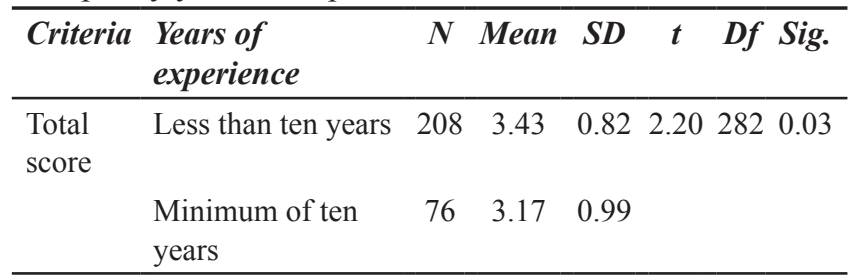

National Standard Higher Education Foundation (NQM) and the Nenadal Study (2015) assured that the EFQM is the most comprehensive tool for assessing and ensuring quality in universities and evaluating the future potential of universities via leading indicators.

The study was consistent with the study of Qawasmeh and Al Bourini, 2016, Al-Alfi (2016) and Ahmed (2015) and Salami, and Khajeh, 2013, whose results indicated that the degree of excellence management practice considering the EFQM is a middle score. However, the study differed with the study of Al-Farra and Sahmoud (2015) and Abu Basheer (2015), whose results indicated that the degree of excellence management practice considering the EFQM was high.

\section{Standard 1: Leadership}

The results indicated that the degree of excellence management practice at Taif University for the leadership standard considering the European model of excellence is high with a general mean of 3.61. This result may be attributed to the fact that the university leadership at Taif University provides all 
Table 14. $t$ test to compare the mean scores of the study sample in the total score of the questionnaire according to the number of training programs that were applied at Taif University

\begin{tabular}{|c|c|c|c|c|c|c|c|}
\hline Criteria & Years of experience & Number & Mean & $S D$ & $t$ & $d f$ & Sig. \\
\hline \multirow[t]{2}{*}{ The total score } & Less than ten programs & 225 & 3.33 & 0.85 & 0.88 & 282 & 0.38 \\
\hline & Minimum of ten programs & 59 & 3.45 & 0.97 & & & \\
\hline
\end{tabular}

possibilities that create an encouraging environment for the work of the team. In addition, the university has an open system that interacts with society, which facilitates a culture of change and is committed to the requirements of the process of change to achieve excellence in university performance. This finding is confirmed by the results of the Issawi (2016) study, which indicated a statistically significant effect on the leadership pattern in university performance excellence.

The highest mean score for the leadership is (3.82) for the item (51), which is characterized by university leadership as an example of their behaviors and high morals. This score may explain that Taif University chooses academic leaders according to high standards to serve as role models for bosses in perfect ethics. The arithmetic mean is low $(\mathrm{M}=3.5)$ for item (4), which is "The university leadership authorizes the authorities according to the regulations in a way that ensures the development of performance." This result may be attributed to the fact that the administrative mandate gives a commander the opportunity to carry out his basic tasks and gives the bosses the opportunity to innovate and prepare to take responsibility and strengthen human relations among members of the administrative organization. All means of this dimension that fall under the category of practice is high. The study was consistent with the study of Saada (2013), whose results indicated that the degree of practice of the leadership standard of the standards of the European model of excellence was high.

\section{Standard 2: Policies and Strategies}

The results indicated that the degree of excellence management practice at Taif University for the policy and strategy criterion considering the European model of excellence is average with a general mean of $(\mathrm{M}=3.23)$. A good indicator of the University's attempt to satisfy this criterion may be an indication that further effort is needed to attain this standard to a high degree. The highest mean (3.46) for the item (16) is "the main objectives of the university are continuously developed." This result may be attributed to the degree of participation of faculty members in the development of university policies and strategies. Item (9) is average, which states that "participating in the development of policies and strategies of the work of the university" with a mean of $(M=3.16)$ led to the awareness by the faculty that the goals of the university are constantly developed. However, the lowest mean is $(\mathrm{M}=2.75)$ for item (12), which states "The University is working to know your needs and financial requirements." This result may be explained by the terms of the contract with non-Saudi faculty members, which affected their responses to their satisfaction with the University's knowledge of their financial requirements and needs. This dimension includes eight items: one item shows a high degree of practice and seven items show an average degree of practice.

\section{Standard 3: Human Resources}

The degree of excellence management practice at Taif University to the human resources standard considering the European model of excellence is average with a general mean of $(\mathrm{M}=3.30)$. This finding may be a good indicator of the University's efforts to provide the material and moral potential for the development of faculty members and participate in the activities of the University, which builds transparency and justice among the faculty members. The highest arithmetical mean of items in the HR dimension is $(\mathrm{M}=3.55)$ for item (21), which is "the university updates data and information of the employees constantly". This mean may be attributed to the fact that the Deanship of Academic Development of the University annually updates the data of the members of the faculty, which led to their awareness of the effort exerted by the Deanship of Development and their response to a high degree. The lowest mean is $(M=2.95)$ for item (17), which states "The university offers training programs based on your training needs". This mean may be explained by the lack of sufficient awareness of the faculty members regarding whether the university provides appropriate training programs for their training needs. The university started from the academic year 2017-2018, and a plan was requested to train faculty members based on the training needs of each faculty member. This dimension includes six items: two items show a high degree of practice and four items show an average degree of practice.

\section{Standard 4: Partnership and Resources}

The degree of excellence management practice at Taif University for the criterion of partnership and resources considering the European model of excellence is average with a general mean of $(M=3.24)$. These results may be interpreted as a good indicator of the University's work in the maintenance of its property and control of financial resources, which improved the degree of awareness of faculty members. The highest arithmetical mean of the items in the Partnership and Resources dimension was $(\mathrm{M}=3.45)$ for item (27), which states "the University is working to manage and maintain its information and data"

This finding may be explained by the effort utilized by the Deanship of Information Technology and E-Learning from the Department of Information and Data Management with regard to archiving and preservation. This department works to secure all possible means of modern equipment and 
techniques and clarify the procedures and programs that are important to faculty members. The lowest mean is (3.08) for item (29), which indicates "The University has emergency plans for the safety of the employees of the university and the surrounding environment". This finding may be attributed to the interest in the current period in a significant manner than previously announced and the number and departments for all safety procedures for university staff and the surrounding environment, including the hotlines for the morning and evening period of security and safety personnel in the event of (electric contact, quarrel, fire, injury), which led to the average recognition of faculty members. This dimension includes eight items: two items show a high degree of practice and six items show an average degree of practice.

\section{Standard 5: Processes, Products and Services}

The degree of excellence management practice at Taif University for the standard of processes, products and services considering the European model of excellence is average with a general mean of $(M=3.29)$. This finding may be interpreted as a suitable indicator of the University in its attempt to resolve the duplication of performance and communicate with the staff on a regular basis, where an annual meeting of faculty members was held with the president of Taif University and members of the administrative and technical staff in the Great Hall of the University. The highest arithmetic mean for the items in the dimension of processes, products and services is $(\mathrm{M}=3.55)$ for item (31), which is "committed to the employees of the university procedures and processes according to the system." The university trains its staff on the new processes prior to implementation." This result may be explained by the concern of the teaching staff members regarding the teaching staff and committees, which causes the failure to follow the attendance of training courses for new processes before they are continuously applied. This dimension includes eight items: two items shows a high degree of practice and six items show an average degree of practice.

\section{Standard 6: Customer Results (beneficiaries)}

The degree of excellence management practice at Taif University to the criterion of the results of the beneficiaries considering the European model of excellence is average with a general mean is $(\mathrm{M}=3.36)$. This result may be interpreted as a good indication of the University's interest in narrowing the gap between the wishes of the beneficiaries and the University, taking their views and benefiting from them in improving the University's services plans and ensuring transparency. The highest mean of the dimension of the results of the beneficiaries is $(\mathrm{M}=3.53)$ for item (39), which is "The University seeks to achieve the highest quality and excellence in the academic process". This result may be attributed to the interest of Taif University in evaluating the annual faculty members from their supervisors and exchanging visits between colleagues and their students on the system of the university. The University of Taif was a pioneer in the preparation of advanced programs. From 1437-1438, it worked on the implementation of the program transformation project, which is the largest of its kind in the Saudi universities and is consistent with the vision of Kingdom 2030. The National Transition 2020 Program facilitated the development of study programs to ensure the achievement of targeted learning outcomes, bridge the gap between higher education outputs and labor market requirements, develop education and guide students toward appropriate careers and career choices. The lowest mean (3.27) was obtained for item (42), "The University has indicators to measure performance with beneficiaries. This result may be explained by the availability of indicators of performance measurement with beneficiaries and the analysis of the results in the Deanship of University Development, which may not significantly affect the faculty members. This dimension includes six items: two items show a high degree of practice and four items show an average degree of practice.

\section{Standard 7: Human Resources Results}

The degree of excellence management practice at Taif University to the standard of human resources results considering the European model of excellence is average with a general mean of $(\mathrm{M}=3.27)$. This finding may be explained by Taif University's diligent work to address feedback regarding training programs and correlate the results of the performance assessment and promotion of members. The University also works to reward outstanding members. The highest arithmetical mean of the items in the human resource results dimension is (3.55) for item (47), which is "the university inquires in the absence of the employee for reasons." This result may be attributed to the attention of the personnel administration at the university to the faculty members and their attendance and discipline to achieving excellence in Educational process. The lowest mean is (3.11) for item (46), "The university benefits from measuring the level of satisfaction of university employees to improve the working environment". This result may be considered a remarkable beginning to recognize how the faculty members benefit the university and measure the level of satisfaction of its employees in improving the working environment. This dimension includes six items: one item shows a high degree of practice and five items show an average degree of practice.

\section{Standard 8: Community Outcomes}

The degree of excellence management practice at Taif University for the criterion of the results of society considering the European model of excellence is high with a general average of (3.54). This finding may be attributed to the University's documentation of each contribution to the community on the university's website and social networking sites (Twitter-snap chat) and encouragement of the employees of the university to provide community services, especially faculty members, which led to the high awareness of faculty members of this dimension.

The highest arithmetical mean of the items in the society results dimension was (3.76) for item (51) The University uses a variety of measuring tools to study and measure the society's opinion about its services." This result may be attributed to the University's attempt to better satisfy the community's satisfaction with its services. The lowest arithmetic 
mean was $(\mathrm{M}=3.30)$ for item (53), which is "the university shares with the local community events and national events". This mean may be attributed to the University's interest in documenting its participation with the local community in the national events and events, including the participation of the university in the Gulf Campaign to raise awareness of cancer in the first week of February 2017. This dimension includes five items: three items show a high degree of practice and two items show an average degree of practice.

\section{Standard 9: Key Performance Results}

The degree of excellence management practice at Taif University to the standard of performance results considering the European model of excellence is high with a general average of 3.44. This finding may be attributed to the interest of the Deanship of University Development to provide indicators for each period of time to provide appropriate service and attention to previous assessments to continuously modify the procedural goals of the University continuously. The highest mean score in the items of this dimension of the main performance results was (3.54) for item (57), which is "the development units request reports to verify the completion of what is planned". This score may be explained by the high interest of the Deanship of University Development to request reports from the colleges and Deans of Supportive Studies to ensure the completion of the planning of the evidence. The lowest mean is $(\mathrm{M}=3.33)$ for item (59), "The university occupies a distinguished place among the public and private universities". This mean may be attributed to the comparison of faculty members of the university with the old universities and is a good indicator of their recognition of the university as an excellent institution. This dimension includes five items: four items show a high degree of practice and one item shows an average degree of practice.

\section{Discussion of the Results of the Second Question}

The results indicated statistically significant differences in the total score of all standards of the EFQM at Taif University due to the gender variable. The differences were in favor of females, which may be attributed to the fact that the female faculty members are more aware of the EFQM than the males. The current status of the university is also empowering women to achieve the vision of the Kingdom of 2030, which motivates women to prove and distinguish themselves and distinguish the institution to which they belong.

The results of this study differ from the results of the Ahmed (2015) study, which indicated a lack of statistically significant differences in the total score of the European model of excellence criteria due to gender. The results also revealed a lack of statistically significant differences at the level of $(0.05)$ in the total score for all standards of the EFQM at Taif University due to the variable type of college. This finding may be attributed to the practice of excellence management standards considering the EFQM, which is distinct and specific to all faculty members of different specialties that work at the same university. The results may be explained considering all faculty members have the same policies, regulations, procedures, processes and decisions according to the university regulations, which reflected on the similar results of the evaluation of both majors.

Statistically significant differences were observed at the level of (0.05) in the total score for the practice of standards according to the academic rank among the arithmetic average of the responses of the associate professors, professors and assistant professors. The differences were in favor of the associate professors because faculty members with the rank of associate professor included experience and the pursuit of excellence and promotion. Thus, the degree of the university's practice of the standards of the European model of excellence was the highest for associate professors compared with faculty members with the rank of professor and assistant professor.

The results revealed statistically significant differences at the level of $(0.05)$ in the total score of all standards due to the number of years of experience at Taif University and the differences between faculty members with less than ten years of experience and faculty members with a minimum of ten years of experience. This finding may be attributed to the fact that faculty members with less than ten years of experience have the initiative and interest in following up with the University's practice of excellence management considering the EFQM criteria for development and upgrading compared with faculty members with more than ten years of experience.

However, the results of this study differ with the results of the study of Ahmed (2015), which indicated a lack of statistically significant differences in the total score of the standards of the European model of excellence due to years of experience. The results revealed a lack of statistically significant differences at the level of (0.05) in the total score among the means of the degrees of excellence management practice at Taif University considering the European model of excellence, despite the different number of training programs provided by the university. This finding may be attributed to the fact that the practice of excellence management standards considering the European Model of Excellence (EFQM) is clear and specific and all faculty are aware of these standards despite the different number of training programs that have been implemented at the university.

\section{CONCLUSION}

Theoretically, this study is a response to the recommendations of many previous studies, conferences and contemporary trends in achieving excellence at the level of institutions of higher education, which emphasizes the importance of development in universities to increase competitiveness. Providing Arab libraries with a study of the application of the EFQM standards in Saudi universities and expanding the information in this field to Taif University in the Kingdom of Saudi Arabia.

Practically, the findings will assist universities officials and leaders to adopt training programs to raise leadership awareness of the European model of excellence and its application. The findings show there is need to work on the development of procedures and mechanisms to satisfy the requirements of the standards of excellence management in the administrative work environment at the University of Taif. This course will reflect the development of the Uni- 
versity. The study contributes to management excellence in achieving higher levels of satisfaction of the employees of the university and the beneficiaries of the services inside and outside Taif University.

The limitation of the study was that the questionnaire was applied to faculty members at Taif University at the headquarters of Al-Hawiyah in the second semester of 20172018. Based on the results of the study, the researcher recommends that the university increase its efforts to attain a higher degree of excellence management practice considering the EFQM. Conducting similar studies of state and private universities in the Kingdom and comparing the results, further research may shed light on assessing excellence management.

\section{REFERENCES}

Abu Basheer, D. (2015). Applying the Enablers Criteria of EFQM Excellence Model in the Palestinian Universities in Gaza Strip (Master's thesis in Business Administration). Al-y University. Gaza.

Ahmed, M. (2015). Development of the institutional performance of the University of South Valley in light of the excellence criteria of the European Foundation for Quality Management: European model of excellence management. Journal of Educational Administration: The Egyptian Association for Comparative Education and Educational Management, Cairo, 15,176.

Al-Alfi, H. (2016). The European Model (EFQM) for excellence and requirements for meeting its standards at Hail University. The Future of Arab Education, 23, 104-128.

Al-Farra, M., \& Sahmoud, E. (2015). The reality of excellence management at Al-Aqsa University according to the European Model of Excellence (EFQM). Journal of the Islamic University for Economic and Administrative Studies, 23(2), 1-29.

Al-Hadi, S. (2013). Managing the change of Arab higher education institutions towards quality and performance excellence. The Arab Journal for Quality Assurance of University Education, 11, 246-255.

Al-Salateen, A. (2014). Achieving quality and excellence in higher education institutions: Research and scientific studies "Achieving academic excellence in the light of some international practices and trends" Dar Al-Hamed for publication and distribution: Jordan.

Al-Soussi, Y. (2015). The degree of technical colleges' practice in the governorates of Gaza to manage excellence and its relationship to competitive advantage (Unpublished master's thesis), Islamic University, Gaza.

Arif, A. (2013). The European Quality Model (EFQM) as an input to performance development: what it is and where to apply and potential obstacles. Arab Journal of Management, Arab Organization for Administrative Development, Egypt, 23.

Bashewa, H., El Barouari, N., \& Ishouni, M. (2013). Institutional Excellence Quality Introduction and Best Practices Principles and Applications. Dar Al Warraq for Publishing and Distribution: Jordan.
Consortium for Excellence in Higher Education. (2003). Embracing Excellence in Education. Sheffield Hallam University.

Garbarova, M. (2017). Improving human resources management using the EFQM Excellence Model, International Journal of Organizational Leadership, 6, 335-339.

Ghasemi, M., Hashemzehi, A., Arjmand, F., Ghaleno,J. D., Reza bondehi, R., Kaffash, S., Amini, S., Yadegari, A. R., Mir, E. K., \& Moghaddam, A.G. (2016). Role of Organizational Excellence Model (EFQM) On Organizational Productivity In Zahedan Azad University. Iloabj Journal, 7(1), 410-420.

Heydari, M., \& Davoodi, S. (2013). A Study of the Relationship between Organizational Learning and EFQM Excellence Model in University of Tehran, European Online Journal of Natural and Social Sciences, 2(3), 1987-1991.

Issawi, N. (2016). Change Management as an Intermediate Variant for the Influence of the Leadership Style on Excellence in University Performance: Applied to Administrative Leaders at Tabuk University in Saudi Arabia, Journal of Arab Organization for Administrative Development, 36(1), pp. 1-62.

Khajeh, M., \& Salami, H. (2013). Performance Evaluation of Islamic Azad University, Qom Branch, Using the EFQM Organizational Excellence Model, Quarterly of Education Strategies in Medical Sciences, 6(1), 43-48.

Mule, G. (2016). EFQM In The Higher Education. http:// documents.uji.es/alfresco/d/d/workspace/SpacesStore/ fe268fa4-8355-4c1b-9f56-8be16fb 1a2f1/g.mule-educsuperior.pdf?guest $=$ true

Nenadal, J. (2015). Comprehensive quality assessment of Czech higher education institutions. International Journal of Quality and Service Sciences, 7(2/3), 138-150.

Qawasmeh, F., \& AL Bourini, F. (2016). Assessing University Excellence Management Practices By using the European Excellence Model according to Students, and Employees Perspectives in Jadara University, Arab Economic \& Business Journal,11, 93-104.

Qurazi, M. (2018). The philosophy of management of institutional excellence in education and international, Arab and local models. The Center for Professional Experiences of Management, Cairo.

Saada, I. (2013). Applying Leadership Criterion of EFQM Excellence Model In Higher Education Institutions UCAS as a Case Study. Thesis Master in Business Administration. Islamic University. Gaza.

Sarialtin, H. (2017). Benchmarking Implementations Of Sakarya University In The Framework Of EFQM Model. The Online Journal of Quality in Higher Education, 4(4),1-5.

Steed, C. (2002). Excellence in Higher Education. Evaluating the implementation of the EFQM Excellence Model

in Higher Education in the UK. Retrieved from http://ids. hof.uni-halle.de/documents/t761.pdf

Zeps, A, Iljins, J., \& Ribickis, L. (2017). Integration of EFQM Excellence Model in RTU Development Strategy: Pilot Project Review. Retrieved from https://doi. org/10.3846/cbme.2017.044 